\title{
Accounting
}

\section{The effect of corporate governance indicators on enhancing the financial performance of industrial listed companies on the Amman Stock Exchange}

\author{
Thaer Ahmad Abutaber ${ }^{a^{*}}$, Ahmad Eqab Al Bzur ${ }^{b}$, Mohammad Husam Odeha, Mustafa \\ Alathamneh $^{a}$, Manaf Al-Okaily ${ }^{\mathrm{a}}$ and Mohammad Kamal Afaneh
}

\section{H R O N I C L E}

\section{Article history:} \\ Received: July 25, 2020 \\ Received in revised format: \\ September 302020 \\ Accepted: November 7, 2020 \\ Available online: \\ November 7, 2020 \\ Keywords: \\ Corporate Governance \\ Firms Performance \\ Industrial Companies
}

${ }^{a}$ School of Business, Jadara University, Irbid, Jordan

${ }^{b}$ School of Business, Northern Border University, Rafha, Saudi Arabia

${ }^{c}$ Faculty of Economic and Business administration, Al Imam Mohammad Ibn Saud Islamic University. Saudi Arabia

\section{A B S T R A C T}

\begin{abstract}
This paper investigated the impact of corporate governance on enhancing the financial performance of industrial companies. The sample of the research consisted of 55 industrial companies listed at the Amman Stock Exchange (ASE) during the period 2014-2018. Data were collected from the firms' annual financial statements using content analysis approach. The results confirmed that the audit committee and ownership structure had positive and significant effects on two dimensions of financial performance. In view of research findings, the study recommends companies to raise some awareness about the importance of corporate governance, in addition to strengthening supervisory procedures by legislators.
\end{abstract}

\section{Introduction}

During the past few years, there have been many financial collapses in the world, which affected the global economy as a whole. During the nineties, the global financial crisis shocked the global economic entity. In 2001, the two largest companies in the world, Enron and World.com, collapsed. This led to the attention of all responsible and concerned parties about the reasons for the collapse of these companies specifically, and through the search and scrutiny of that incident, it was found that there is a big problem known in the economy as the Agency Problem. This is associated with the conflict between the interests of the administration and the manager in particular with the interests and objectives of the shareholders, so that if the goal of the manager was personal goals for his benefit and not for the benefit of the company and shareholders, then it will ultimately lead to the collapse of these companies. In addition to not to establish the basic and main rules, this defines all the functions in the company. The best solution was to put in place many laws and regulations that obligate companies to apply and adhere to them in a better way. These rules were defined in the name of corporate governance. Institutional governance included many rules and laws that clarify the tasks assigned to all sections of the company. In addition to the importance of corporate governance in the protection of shareholders and their rights, it is a major source of the company's annual debt. By applying the criteria of corporate governance, the company's commitment to the principles, thereby ensuring the protection and satisfaction of shareholders' rights from any risks that the company is exposed to. When talking about institutional governance, it must be

* Corresponding author.

E-mail address: thaer@jadara.edu.jo (T. A. Abutaber) 
linked to the financial performance of the company. By studying several studies on institutional governance, it was found that it had a significant impact on the performance of the company. This will be highlighted in the current study where this study will be applied to the industrial companies. The problem of the study can be formulated with the main question of the study:

Is there any effect of corporate governance on enhancing the performance of industrial companies listed on the Amman Stock Exchange (ASE)?

Sub- Questions as following:

- Is there any effect of the number of the board members on enhancing the financial performance of the industrial companies listed on the ASE?

- Is there any effect of the audit committee on enhancing the financial performance in the industrial companies listed on the ASE?

- Is there any effect of the ownership structure on enhancing the financial performance in the industrial companies listed on the ASE?

- Is there any effect of focusing the ownership on enhancing the financial performance in the industrial companies listed on the ASE?

The importance of the study: This study will be significant in several aspects including:

1. It will provide recent results on the importance of corporate governance indicators on the financial performance of companies.

2. To clarify the impact of the indicators of corporate governance indicators in enhancing the financial performance of companies

3. This study will be of interest to the companies so that they will explain to them the importance of applying the corporate governance and indicators in the company with all its provisions and instructions and the impact on the financial performance related.

\section{Objectives of the study}

The study aimed primarily at the following:

- Determine the impact of corporate governance on enhancing the performance of industrial companies listed at the Amman Stock Exchange,

- Determine the impact of corporate governance indicators on enhancing the rate of return on assets of industrial companies listed at the Amman Stock Exchange,

- Determine the impact of corporate governance indicators on enhancing the rate of return on equity of industrial companies listed at the Amman Stock Exchange,

- Determine the impact of corporate governance indicators on enhancing the earnings per share of industrial companies listed at the Amman Stock Exchange.

\section{Study Hypotheses}

\subsection{The first main hypothesis}

$\mathrm{H}_{0.1}$ There is no effect of corporation governance indicators on enhancing the ROA's financial performance of the industrial companies listed on the ASE.

\subsubsection{First sub-hypotheses}

$\mathrm{H}_{0.1-1}$ : There is no effect of the number of the board members on enhancing the ROA's financial performance of the industrial companies listed on the ASE.

$\mathrm{H}_{0.1-2}$ : There is no effect of the audit committee on enhancing the ROA's financial performance of the industrial companies listed on the ASE.

$\mathrm{H}_{0.1-3:}$ There is no effect of the ownership structure on enhancing the ROA's financial performance of the industrial companies listed on the ASE.

$\mathrm{H}_{0.1-4:}$ There is no effect of focusing the ownership on enhancing the ROA's financial performance of the industrial companies listed on the ASE. 
$\mathrm{H}_{0.2 \text { : }}$ There is no effect of corporation governance indicators on enhancing the ROE's financial performance of the industrial companies listed on the ASE.

\subsubsection{Second sub-hypotheses}

$\mathrm{H}_{0.2-1}$ : There is no effect of the number of the board members on enhancing the ROE's financial performance of the industrial companies listed on the ASE.

$\mathrm{H}_{0.2-1}$ : There is no effect of the audit committee on enhancing the ROE's financial performance of the industrial companies listed on the ASE.

$\mathrm{H}_{0.2-1}$ : There is no effect of the ownership structure on enhancing the ROE's financial performance of the industrial companies listed on the ASE.

$\mathrm{H}_{0.2-1}$ : There is no effect of focusing the ownership on enhancing the ROE's financial performance of the industrial companies listed on the ASE.

\subsection{The third main hypothesis}

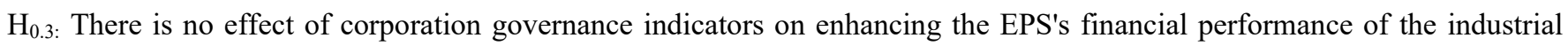
companies listed on the ASE.

\subsubsection{Third sub-hypotheses}

$\mathrm{H}_{0.3-1}$ : There is no effect of the number of the board members on enhancing the EPS's financial performance of the industrial companies listed on the ASE.

$\mathrm{H}_{0.3-1}$ : There is no effect of the audit committee on enhancing the EPS's financial performance of the industrial companies listed on the ASE.

$\mathrm{H}_{0.3-1}$ : There is no effect of the ownership structure on enhancing the EPS's financial performance of the industrial companies listed on the ASE.

$\mathrm{H}_{0.3-1}$ : There is no effect of focusing the ownership on enhancing the EPS's financial performance of the industrial companies listed on the ASE.

\section{Theoretical framework and literature review}

This section explains the concept of corporate governance or so-called corporate governance in terms of its definition and historical development of governance, its importance, and its objectives for institutional governance.

\subsection{Definition of Institutional Governance}

According to Organization for Economic Cooperation and Development (2004), corporate governance is defined as a set of relationships between those who are responsible for the company, the board of directors, shareholders and many of contributor (Arafah \& Meligi, 2015). In addition, Khadr (2012) and Maswadeh (2018) defined corporate governance as a set of rules governing the interrelations between the company and the various stakeholders, in a measure of transparency and accountability, which helps to sustain the business and increase the efficiency of the company to manage its operations and improve its competitiveness in the markets. The Jordan Securities Commission (JSC) has issued the Public Shareholding Corporate Governance Index, which is listed on the Amman Stock Exchange in September 2006 to support economic progress TSC, (2017). From the researchers' perspective, corporate governance is a number of rules and administrative and accounting systems lead to control the work of the company in a neutral, efficient, objective and transparent manner, such as the rights of employees and management and shareholders in addition to all external parties that deal with the company.

\subsection{The Historical Evolution of Corporate Governance}

The first to consider the separation of ownership from management began by Adolf and Gardener men, in a book issued in 1932, in their book on institutions that develop and grow at a high level when separation can occur between ownership and management. In 1976, Meckling and Jensen (1993) worked on institutional governance and showed how important it was to reduce and minimize problems between ownership and management. They focused on several theories such as the agency theory, the ownership rights theory and the ownership structure theory (Jensen et al., 1976). It can be noted that in the ten years 
of the twentieth century, attention was increased to the concept of corporate governance, which was the beginning of many specialists, especially after the collapse of the Bank of Credit and Trade and the bankruptcy of Maxwell UK that has been affecting the London Stock Exchange in the years (1991-1992). This was accompanied by the formation of a committee to study the causes of the collapse of the bankruptcy of listed companies in the market, when the report on corporate governance was issued on December 1, 1992, and the name of the report was (Cadbury). After the series of crises in Asia in 1997, followed by Russia and Latin America, which topped the scandal of the two most famous companies, WorldCom, Enron, in 2001, and the financial crisis of 2008, such crises have led to experts' research on new tools and indicators for monitoring and follow-up. Knowledge of governance was viewed in a new and varied way by making it a safety valve to protect companies from any possible collapse, (Youssef, 2007).

\subsection{The objectives of corporate governance}

The main objective is to control and guide administrative, financial and technical practices and to work towards the observance of well-defined controls and policies. In Abu Hammam's (2008) study, the objectives of the corporate governance indicators were summarized in several points. The most important of which was the emphasis on the need to comply with all the provisions of the law and work to ensure the review of financial performance. Moreover, working to strengthen the transparency of all transactions related to the company and operations and also to avoid any financial crises due to the great impact that occurs in the economy.

\subsection{Reasons for the emergence of corporate governance}

One of the main reasons that led to the emergence of corporate governance was mentioned in many studies such as Darwish, (2007), which was the weakness of the legal system. That means that it is not possible to conduct the implementation of contracts and resolve disputes effectively. Besides, he witnesses many cases of financial and administrative corruption, including that it may require global investment institutions a high level of governance in order to accept the direction of investment. As well as the continuing demand to pay attention to aspects of ethics and code of contract in order to protect the interests of individuals and society. Examples include the protection of the rights of small shareholders and other parties involved in the company in terms of the expectation of collusion with the senior shareholders with management to achieve their own interests at the expense of others.

\subsection{Corporate governance indicators}

There are many indicators of corporate governance that have been developed in detail to protect shareholders and contributors from any possible manipulation of the company. The following are some of the corporate governance indicators that have been included in the study variables to measure corporate governance:

1. The size of the Directors Board: A key factor for the success of the company wherein the law of governance, it is emphasized that the number of members of the Board of Directors must not exceed 13 members and not less than 7 members, who possess scientific and professional certificates commensurate with the company's status and nature. This was confirmed by Herdjiono and Sari (2017); however, some researchers have a weak relationship between board size and return on equity as shown in Dzingai and Fakoya (2017) in the results of his study as well as Palaniappan (2017) study.

2. Audit Committee: the corporate governance rules stipulate that the Audit Committee must be a non-executive Board member, at least two of whom have scientific and practical experience in accounting and financial management. The auditors are approving the annual report of the company's declared business to the shareholders. The company has an official policy for the recycling of external auditors and it does not last for more than five consecutive years. In addition, the company must have a compliance control department with specific functions.

3. Duality the positions of the Chairman of the Board of Directors and the Executive Director: Corporate governance provided that there should be a separation between the position of Chairman of the Board of Directors and Executive Director. However, $\mathrm{Vu}$ and Nguyen (2017) declared that there is no on that. The Board member must be at least 25 years old when he is a member of the Board. In addition, the Executive Director is a member of the Board of Directors of other companies with a maximum of two companies.

4. Ownership structure: Corporate governance has defined a structure of ownership, including managers who have shares of at least $1 \%$ and the most $30 \%$ of subscribed shares. The proportion of shares owned by the largest shareholder, whether indicators corporate, or a group of related, joint and family interests, does not exceed the contribution of $10 \%$ of the company's shares, which is confirmed by Darko et al. (2016) in his study.

5. The concentration of ownership: Corporate governance has recently introduced a concentration of ownership, called senior shareholders, individuals or persons over $1 \%$, defined by a percentage of the annual financial report published by the company. 
Corporate governance offers many advantages to the society, the company, the investors in the company and others. The most important advantages include, CIPE (2008): improving the competitiveness and value of economic units and raise their value, Suleiman, (2009). Work effectively to control the performance of economic units while strengthening accounting accountability. As well as ensuring that the operational, financial and monetary performance of the economic unit is reviewed. It helps to assess the performance of senior management, enhance accountability, raise trust and deepen a culture of compliance with agreed laws, principles and standards. It is also important to work to maximize the profits of the economic unit and increase the confidence of all investors in the market in order to support national investment, as well as achieve justice and transparency and work to fight corruption and take into account the interests of the various parties (Kowalewski, 2016).

\subsection{Disadvantages of corporate governance}

Sartawi (2015) and Abutaber (2015) considered that corporate governance has several disadvantages, for instance, it is not possible to apply all its instructions because of the non-conformity of its provisions to all companies, and it focuses the institutional governance in its articles on shareholders and their rights only. In addition to the absence of a law on institutional governance that punishes any management of the company did not follow its instructions.

\subsection{Financial Performance}

The intuitions have financial performance measures as part of their performance management and one of the responsibilities of a finance manager is evaluating and monitoring financial performance. The manager decides how the evaluation will be conducted; collect data that accurately reflects the performance of the enterprises and develops a set of standards for measuring performance. If performance is not satisfactory, management must identify and implement strategies that will lead to improved performance (Maswadeh, 2018).

\subsubsection{Corporate financial performance}

It can be measured by several measures, Sartawi (2015):

1. Return on Assets (ROA): it reflects the level of performance and profitability of the company. The higher the percentage, the clearer the level of the company's business in general, as evidenced by the rate of return on assets depends on net income and total assets.

$$
R O A=(\text { Net Income } / \text { Total Assets }) \times(100 \%)
$$

2. Return on Equity (ROE): The Company's performance and profitability are also considered to be the second factor of profitability and performance of the company and can be expressed or measured through net income on total equity.

$$
R O E=(\text { Net Income } / \text { Shareholders }) \times 100 \%
$$

3. Earnings per Share (EPS): Earnings per share reflect the earnings per share of the company, and can be based on the earnings per share through the share price of the stock.

\subsubsection{Governance and financial performance}

$$
E P S=(\text { Net Income } / \text { No. of Share }) \times 100 \%
$$

The issue of corporate governance is one of the most important subjects in the world. It has become increasingly important from 2001 until now. This is because it does not contain rules and regulations that regulate the work of the company and mitigate manipulations that occur and affect the interests of shareholders. A good corporate governance application in the company should lead to an improvement in stock market prices and thus improved returns for shareholders (Yahyaoui \& Bouslima, 2012; Sheikh et al., 2013). It can be concluded that governance improves the quality and efficiency of leadership in the company, and its contribution to transparency in its operations (Khoury, 2003). The importance of corporate governance lies in the state as a whole not only on the company's business. All that has been control in the company's business and achieve high returns with low risk, it indicates that the lack of borrowing or bankruptcy, which affects the economy of the country in a good manner, and the company is counted as one unit of the total units that the economy of the state is based on. Thereby, prompting new investors to invest in the company in the state (Qabajah, 2008). It can be concluded that corporate governance is an important source both at the company level and at the state level in terms of investment stimulation and achieving the least risk and possible loss to be exposed to.

\section{Methodology}

Type and nature of the study: The study depends on the nature of the analytical descriptive approach, which focuses on obtaining certain data and then analyzed to get the best results.

The study population and sample: The study population is composed of all industrial companies listed on the Amman Stock Exchange, while the study sample consisted of (55) industrial companies listed on the ASE during the year 2015. 
Methods of data collection: Data collection was obtained from secondary sources, which includes a reference to many previous studies, books, scientific articles in published scientific journals.

\section{Study model:}

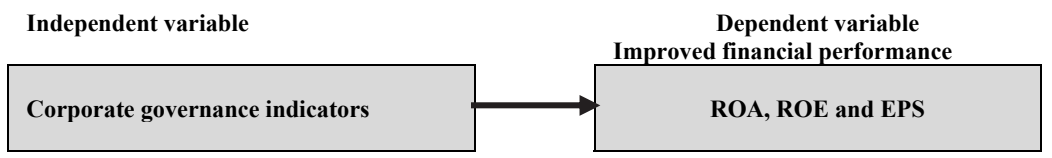

Statistical methods: SPSS was used in many fields of sciences as accounting and management science (Al-Okaily et al., 2019). Accordingly, the study data were analyzed through SPSS and obtained many statistical methods such as:

1. Descriptive statistics: including mean and standard deviation.

2. Multiple regression analysis: to test the hypotheses of the study.

\section{Discussion of the results:}

\subsection{Results of the first main hypothesis}

Table 1 exhibits the results of regression between the effect of independent variables (Corporate Governance Indicators) on the dependent variable (financial performance) which indicates that the model is valid for testing sub-hypotheses based on the calculated $\mathrm{F}$ value of 5.073 which is statistically significant at $5 \%$, where total of the interpretation of Corporate Governance Indicators with its two dimensions of the difference in (ROA) financial performance (Adj. $\mathrm{R}^{2}$ ) coefficient of the determination yields the rate of $17.1 \%$; this is the basis of the decision to reject the null hypothesis, which assumes that there is no effect of Corporate Governance Indicators to enhance ROA as financial performance, and thus we accept the alternative hypothesis.

Table 1

The results of regression analysis for testing the main hypothesis

\begin{tabular}{llll}
\hline variables & B Coefficient & $t$-statistics & Prob. \\
\hline constant & -13.62865394 & $3.398018698-$ & 0.783551146 \\
Number of the board members & 0.071282064 & 0.275681125 & 0.017857561 \\
Audit committee & 3.026757974 & 2.42186116 & 0.022706631 \\
Ownership structure & 5.210518806 & 2.326296468 & 0.621697478 \\
Focusing the ownership & -1.1181648 & $0.495499787-$ & 0.001132 \\
\hline F- statistics & 5.072693 & P-value & 0.212935 \\
Adj. $\mathrm{R}^{2}$ & 0.170959 & $\mathrm{R}^{2}$ & 80 \\
\hline
\end{tabular}

\subsubsection{First sub-hypotheses}

Table 1 shows that each indicators of corporate governance affects financial performance, therefore, each indicator represents a sub-hypothesis of the main hypothesis, where the calculated value of $t$ was measured, and two the indicators of the independent variables were statistically significant the beta values shown in the table indicate that the variable in Audit committee with Beta value (3.03) and the variable of Ownership structure value of Beta (5.21); Since significant level of two sub-hypotheses was less than $5 \%$, the null hypothesis of the two sub-hypotheses was rejected (in other words: $\mathrm{H}_{0.2-2} \& \mathrm{H}_{0.2-3}$ ), thus accepting the alternative hypothesis of the sub-hypotheses. The two indicators of the independent variables were statistically insignificant to Number of the board members and Focusing the ownership; Since the significant level of the two sub-hypotheses was more than $5 \%$, the null hypothesis of the two sub-hypotheses was accepted (in other words: $\mathrm{H}_{0.2-1} \& \mathrm{H}_{0.2-4}$ ), and reject the alternative hypothesis of the sub-hypotheses

\section{Table 2}

The results of regression analysis for testing the first sub-hypothesis

\begin{tabular}{|c|c|c|c|}
\hline variables & B Coefficient & $t$ - statistics & Prob. \\
\hline constant & -24.12426767 & -3.1996686 & 0.002017271 \\
\hline Number of the board members & -0.154826844 & -0.318530547 & 0.750967871 \\
\hline Audit committee & 4.965645692 & 2.113612343 & 0.037873952 \\
\hline Ownership structure & 12.26707811 & 2.913421258 & 0.004708367 \\
\hline Focusing the ownership & -3.091717661 & -0.728809227 & 0.468388092 \\
\hline F- statistics & 4.470947325 & P-value & 0.002703548 \\
\hline \multirow[t]{2}{*}{ Adj. $R^{2}$} & 0.149474837 & $\mathrm{R}^{2}$ & 0.192539403 \\
\hline & & Observations No. & 80 \\
\hline
\end{tabular}


Table 2 exhibits the results of regression between the effect of independent variables (Corporate Governance Indicators) on the dependent variable (financial performance) which indicates that the model is valid for testing sub-hypotheses based on the calculated $\mathrm{F}$ value of 4.471 which is statistically significant at $5 \%$, where total of the interpretation of Corporate Governance Indicators with its two dimensions of the difference in (ROE) financial performance (Adj. $\mathrm{R}^{2}$ ) coefficient of the determination of the rate of $14.9 \%$; which is the basis of the decision to reject the null hypothesis, which assumes that there is no effect of Corporate Governance Indicators to enhance ROE which is the financial performance, and thus accept the alternative hypothesis.

\subsubsection{Second sub-hypotheses}

Table 3 shows that each indicators of corporate governance affects financial performance, therefore, each indicator represents a sub-hypothesis of the main hypothesis, where the calculated value of $t$ was measured, and two the indicators of the independent variables were statistically significant and the beta values shown in the table indicate that the variable in Audit committee with Beta value (4.97) and the variable of Ownership structure value of Beta (12.27); Since the significant level of two sub-hypotheses was less than $5 \%$, the null hypothesis of the two sub-hypotheses was rejected (in other words: $\mathrm{H}_{0.1-2} \& \mathrm{H}_{0.1-3}$ ), thus accepting the alternative hypothesis of the sub-hypotheses. While the two indicators of the independent variables were statistically insignificant to Number of the board members and Focusing the ownership; Since significant level of two sub-hypotheses was more than $5 \%$, the null hypothesis of the two sub-hypotheses was accepted (in other words: $\mathrm{H}_{0.1-1} \& \mathrm{H}_{0.1-4}$ ), thus reject the alternative hypothesis of the sub-hypotheses

\section{Table 3}

The results of testing the second hypothesis

\begin{tabular}{llll}
\hline variables & B Coefficient & $t$-statistics & Prob. \\
\hline constant & 2.92687524 & 0.941688555 & 0.349375493 \\
Number of the board members & -0.035289895 & -0.176119488 & 0.860674755 \\
Audit committee & 0.326754946 & 0.337383623 & 0.736770139 \\
Ownership structure & -5.495179393 & -3.165893122 & 0.002235251 \\
Focusing the ownership & 2.014588168 & 1.152000148 & 0.252979952 \\
\hline F- statistics & 2.78944516 & P-value & 0.032276 \\
Adj. $R^{2}$ & 0.083078 & $\mathrm{R}^{2}$ & 0.129504 \\
& & Observations No. & 80 \\
\hline
\end{tabular}

\subsection{Results of third main hypothesis}

Table 3 presents the results of regression between the effect of independent variables (Corporate Governance Indicators) on the dependent variable (financial performance) which indicates that the model is valid for testing sub-hypotheses based on the calculated $\mathrm{F}$ value of 2.789 which is statistically significant at $5 \%$, where total of the interpretation of Corporate Governance Indicators with its two dimensions of the difference in (EPS) financial performance (Adj. $\mathrm{R}^{2}$ ) coefficient of the determination of the rate of $8.31 \%$; this is the basis of the decision to reject the null hypothesis, which assumes that there is no effect of Corporate Governance Indicators to enhance EPS the financial performance, and thus accept the alternative hypothesis.

\subsubsection{Third sub-hypotheses}

Table 3 shows that each indicators of corporate governance affects financial performance, therefore, each indicator represents a sub-hypothesis of the main hypothesis, where the calculated value of $t$ was calculated, and one indicator of the independent variables were statistically significant and the beta values shown in the table indicate the variable in Ownership structure with Beta value (-5.50); Since significant level of one sub-hypotheses was less than 5\%, the null hypothesis of the one sub-hypotheses was rejected (in other words: $\mathrm{H}_{0.3-3}$ ), thus accepting the alternative hypothesis of the sub-hypotheses. while the three indicators of the independent variables were statistically insignificant to Number of the board members, Audit committee and Focusing the ownership; Since significant level of three sub-hypotheses was more than $5 \%$, the null hypothesis of the three sub-hypotheses was accepted (in other words: $\mathrm{H}_{0.3-1}, \mathrm{H}_{0.3-2} \& \mathrm{H}_{0.3-4}$ ), thus reject the alternative hypothesis of the sub-hypotheses

\section{Conclusions and recommendations}

The principal purpose of this study was to investigate the association between the indicators of corporate governance and the three dimensions of corporate financial performance, the three dimensions of corporate financial performance were Return on Assets, Return on Equity and Earnings per share. Empirical findings, based on linear multiple regression analysis, have indicated the association between major indicators of corporate governance and the three dimensions of corporate performance were different. In general, empirical findings have suggested that audit committee and ownership structure affected the two dimensions of corporate financial performance (ROA \& ROE) and had positive effects, but ownership structure had negative 
effect on EPS, while number of the board members and focusing the ownership had no effect on any dimension of corporate financial performance. These results are indicative of increase awareness and interest by managers to the importance of adherence to the indicators of governance. Our recommendation is to increase employees' awareness about the importance of corporate governance, in addition to strengthening supervisory procedures by legislators

\section{References}

Abu Hammam, M. (2008). The Effect of Application of Governance Rules on Accounting Disclosure and Quality of Financial Reports, Unpublished Master Thesis, Islamic University of Gaza, Palestine.

Abutaber, T. (2015). The impact of Activity Based Costing (ABC) application on product quality. Australian Journal of Basic and Applied Sciences, 9, 219-223.

Al-Okaily, M., Abd Rahman, M. S., \& Ali, A. (2019). Factors affecting the acceptance of mobile payment systems in Jordan: The moderating role of Trust. Journal of Information System and Technology Management, 4(15), 16-26.

Arafah, N., \& Meligi, M. (2015). The impact of corporate governance on the value added of capital in kind and intellectual property: An empirical study on Saudi registered companies, Saudi Journal of Science, 2(1), 1-34.

Center for International Private Enterprise (CIPE), (2008). Corporate Governance in the 21st Century.

Darko, J., Aribi, Z. A., \& Uzonwanne, G. C. (2016). Corporate governance: the impact of director and board structure, ownership structure and corporate control on the performance of listed companies on the Ghana stock exchange. Corporate Governance, $16(2), 259-277$.

Darwish, A. (2007). Corporate governance and the role of the Board of Directors. Union of Arab Banks.

Dzingai, I., \& Fakoya, M. B. (2017). Effect of corporate governance structure on the financial performance of Johannesburg Stock Exchange (JSE)-listed mining firms. Sustainability, 9(6), 867.

Herdjiono, I., \& Sari, I. M. (2017). The effect of corporate governance on the performance of a company. Some empirical findings from Indonesia. Journal of Management and Business Administration. Central Europe, 25(1), 33-52.

$\mathrm{Vu}, \mathrm{N}$. H., \& Nguyen, T. (2017). Impacts of corporate governance on firm performance-Empirical studies of listed Singaporean companies.

Jensen, M., \&Meckling, W. (1976). Theory of the firm: Managerial behavior, agency costs and ownership structure. Journal of Financial Economics, 3, 305-360.

Jensen, M. (1993). The modern industrial revolution exist and the failure of internal control systems. Journal of Finance, 48, 831-850.

Jordan Securities Law (2017).

Khadr, A. (2012). Corporate Governance. University Thought House, Cairo, Egypt.

Khoury, M. (2012). Effect of applying the rules of governance on the quality of accounting disclosure: A field study of the reality of banks and economic institutions in Algeria, Master Thesis published, University of Qusdi Marbah, Ouargla, Algeria.

Kowalewski, O. (2016). Corporate governance and corporate performance: Financial crisis (2008). Management Research Review, 39(11), 1494-1515.

Maswadeh, S., Abutaber, T., \& Alathamneh, M. (2018). The effect of dividends and earnings per share on the stock market value by moderating bank size. Journal of Modern Accounting and Auditing, 14(8), 408-415.

Palaniappan G. (2017). Determinants of corporate financial performance relating to board characteristics of corporate governance in Indian manufacturing industry: An empirical study. European Journal of Management and Business Economics, 26(1), 67-85. https://doi.org/10.1108/EJMBE-07-2017-005

Qabajah, A. Hamed, M., \& Al-Shaqi, I. (2008). Strengthening Corporate Governance in Palestine, published research, Palestinian Economic Policy Research Institute, Palestine.

Sartawi, A. (2015). The impact of corporate governance on the performance of listed companies in the GCC financial markets. Jordanian Journal of Business Administration, 11(3), 705-725.

Sheikh, N., Wang, Z., and Kham, S. (2013). The impact of internal attributes of corporate governance on firm performance. International Journal of Commerce and Management, 23(1), 38-55.

Suleiman, M. (2009). Role of Corporate Governance in the Treatment of Financial and Administrative Corruption, University House, Cairo, Egypt.

Youssef, M. (2007). Corporate Governance between Theory and Practice. Association of Accountants and Auditors, Cairo, Egypt.

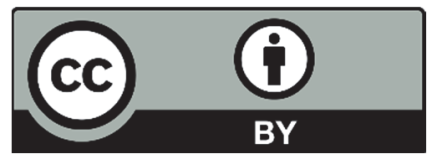

(C) 2021 by the authors; licensee Growing Science, Canada. This is an open access article distributed under the terms and conditions of the Creative Commons Attribution (CC-BY) license (http://creativecommons.org/licenses/by/4.0/). 